\section{International Scientific Journal Theoretical \& Applied Science}

\author{
p-ISSN: 2308-4944 (print) e-ISSN: 2409-0085 (online) \\ Year: $2016 \quad$ Issue: 3 Volume: 35 \\ Published: $30.03 .2016 \quad$ http://T-Science.org
}

SECTION 21. Pedagogy. Psychology. Innovations in the field of education.
Tolkyn Kalbirova

Master of pedagogical sciences, senior teacher, Kazakh National ResearchTechnical University named after K.I.Satpaev kalbirovatol@mail.ru

Akbope Karabayeva

Master of economic sciences, senior teacher, Kazakh National ResearchTechnical University named after K.I.Satpaev k.akbope@list.ru

Akmaral Umirbekova

Master of pedagogical sciences, senior teacher, Kazakh National ResearchTechnical University named after K.I.Satpaev akmaral.apiza@mail.ru

Karlygash Shokaeva

Master of pedagogical sciences, senior teacher, Kazakh National ResearchTechnical University named after K.I.Satpaev shohaeva1976@mail.ru

\section{Dariga Bekova}

Master of pedagogical sciences, senior teacher, Kazakh National ResearchTechnical University named after K.I.Satpaev

Laura Anarbek Master of pedagogical sciences, teacher, Kazakh National ResearchTechnical University named after K.I.Satpaev laura_19@mail.ru

\title{
DEVELOPMENT OF CROSS - CULTURAL COMPETENCE AS A FACTOR OF CULTURAL - LINGUISTIC PERSONALITY FORMATION
}

Abstract: This article is devoted to topical problems of formation of intercultural competence of an individual, which is determined by the trends of modern society and education. Examines the principles and approaches underlying the formation of ability to intercultural communicative competence. The success of intercultural communication depends largely on the professional competence of the teacher. The teacher's task is to create a model of real communication, which contributes to students ' natural desires and need for interaction with others, confidence in themselves and their abilities for communication. The communicative approach means training to dialogue and formation of ability to intercultural interaction that is the basis for the functioning of the Internet.

Key words: Intercultural competence, cultural and linguistic personality, culture, education system, communication, Internet resources, communicative approach, multicultural direction.

Language: English

Citation: Kalbirova T, Karabayeva A, Umirbekova A, Shokaeva K, Bekova D, Anarbek L (2016) DEVELOPMENT OF CROSS - CULTURAL COMPETENCE AS A FACTOR OF CULTURAL - LINGUISTIC PERSONALITY FORMATION. ISJ Theoretical \& Applied Science, 03 (35): 149-153.

Soi: $\underline{\text { http://s-o-i.org/1.1/TAS-03-35-25 Doi: crossef http://dx.doi.org/10.15863/TAS.2016.03.35.25 }}$

\section{Introduction}

Topicality of the theme of personality crosscultural competence formation is stipulated by the trends of modern society and education development. Modern society being at post-industrial or information stage of its development is characterized by intensification of different cultures interaction, wide use of computer equipment, development of telecommunication facilities, globalization of all fields of social life and growth of cross-cultural and 
inter-personal communication, especially, in computer-mediated environment.

Modern school is intended to join future generation to the culture of native country, to cultivate universal human values in them, to develop tolerant attitude to culture of the countries of other peoples and ability to participate in cross-cultural dialogue. Currently, the students get sufficiently extensive knowledge about the countries of language they learn and, at the same time, they come across enormous difficulties in the course of direct or computer-mediated communication with foreigners, demonstrating inability to understand and accept another culture. For this reason, it is possible to acknowledge that there is inconsistency since school students need practical formation of cross-cultural competence, on the one hand, and, the issue of crosscultural competence formation is insufficiently developed in the pedagogic theory, on the other hand [1].

\section{Methodology}

Cross-cultural communication study in education system was initiated by the teachers of foreign languages who first became aware that it was not enough to be fluent in foreign language for efficient communication with the representatives of other cultures. Practice of communication with foreigners proved that even deep knowledge of foreign language did not exclude misunderstanding and conflicts with native-speakers. Therefore, foreign language teaching includes students' knowledge of history, customs, traditions, social organization of the country of language being learned. However, as proved by practice, only theoretic knowledge of the relevant culture appears to be insufficient for conflict-free communication with representatives thereof, it became evident that successful and efficient contacts with the representatives of other cultures were impossible without practical skills in cross-cultural communication. It is necessary to prepare school students to efficient cross-cultural contacts at the level of everyday cross-cultural communication. To this effect, knowledge of crosscultural misunderstanding nature is insufficient, formation of practical skills and competence which would make it possible to understand the representatives of other cultures [2] freely is required here.

At the end of the 90s, the term "cross-cultural competence" became ingrained in the methods of foreign language teaching as an indicator of person's ability to participate in cross-cultural communication efficiently [3].

Competence means ability to carry out the activities creatively based on the motives formed, personal qualities, ability to use regulatory acceptable samples of behavior in the professional conduct. Acquisition of competence forms the basis for development of professionalism and mastership [4].

\section{Research and Results}

Communication is a social-induced process of information transfer and exchange of ideas and feelings between people in different fields of cognitive-labor and creative activity. Although the concept "communication" may be considered as a synonym of the concept "personal interaction", but communication is wider than personal interaction. Personal interaction is verbal and nonverbal interaction implemented in practice. Telling about the essence of "cross-cultural communicative competence" concept, O.A. Leontovich underlines that cross-cultural competence "is an aggregation of three components: linguistic, communicative and cultural competence that have own features different from each of the components taken apart [5]. Linguistic competence is responsible for correct choice of linguistic means adequate for the situation of communication; communicative competence includes mechanisms, methods and strategies required to ensure efficient process of communication; the concept of cultural competence coincides with the concept of cultural literacy and contemplates knowledge of the political realities, phraseological units, terms and etc."

Essence of cross-cultural communicative competence is defined more specifically by I.L. Pluzhnik: "... it (cross-cultural communicative competence) is the functional skills necessary to understand views and opinions of the representatives of other culture, to correct own behavior, to overcome conflicts in the course of communication and to acknowledge the right for existence of different values and rules of behavior..." [6].

Let's define a range of directions for formation of ability to cross-cultural communicative competence in terms of foreign language learning. They include:

- Multicultural direction (enrichment of own culture due to acceptance of another, readiness to acquisition of other culture): acceptance of new knowledge about foreign culture for deeper understanding of own culture; respect for all cultures; vision in foreign culture rather the things that make us closer and unite us than the things which differ us from each other; ability to consider the events and their participants not from own point of view but from the point of view of another culture;

- Tolerance (orientation to interaction, ability to communicate conflict-free): ability to interact with people of another culture with due consideration of their values, standards, ideas; ability to correct their behavior in the course of communication as to a person of another culture; no hardness in behavior; ability to feel with by response to emotions and feelings of foreign culture bearers and to feel and understand state of people mind; 
- Behavioral direction (sociability of behavior): adequate behavior accepted in business professional conduct; ability to reach constructive compromises; ability to come into contact with and keep it;

- Linguistic social cultural direction (use of linguistic means of language in accordance with the cultural standards of language in the professional conduct): ability to exchange opinions; ability to listen actively based on repetition of the foregoing, to summarize, to be attentive to companion; to put issues that contribute to explanation of the foregoing [6].

The task of formation of ability to cross-cultural communicative competence is reached in the course of voice interaction: listening, reading, speaking, writing both in the course of in-class learning and out-of-class work with trainees.

Let's consider the principles and approaches put to the basis of formation of ability to cross-cultural communicative competence.

Let's consider the following:

- Trainees' awareness of own national culture and native language; for this purpose, combination of communicative-activity approach with social-andcultural approach makes it possible to form certain culturological ideas about the countries of co-learned languages, peoples and communities and to get knowledge about culturological materials about the native country, to develop representation of native culture in foreign language in an environment speaking another language under conditions of crosscultural communication;

- Reliance on background knowledge, social and cultural background in terms of which the foreign language being learned operates, since for adequate cross-cultural communication with native speaker we need background knowledge which play some role in use of language and influence foreign communicative competence of trainees;

- Learning of linguistic interaction in terms of cultures dialogue that contemplates extension of cultures and civilizations range, awareness "by trainees that they are cultural-and-historic subjects who are the bearers and expressers of not one but the whole range of mutually-connected cultures for preparation thereof to fulfillment of the role of cultures dialogue subject in society ..." [7];

- Humanistic psychologization of teaching environment understood as nomination of a trainee as the subject of cross-cultural communication and as a subject of linguistic learning process that makes it possible to speak about shift in emphasis in the course of foreign language learning from teaching activity to activity of a trainee and formation of his/her creative individual;

- Interactive type of trainees' activities that contemplates use of modern technologies, providing updating and development of school students' personal qualities (learning in cooperation, projects method, information technologies (Internet), distance learning based on computer telecommunications); differentiated approach to trainees that induce to choose, to be independent and active and to develop reflection.

Based on the structure of cross-cultural communicative competence and considering the principles of formation of functional skills that make it possible to evaluate the communicative situation adequately and to implement a communicative intention, let's define the pedagogic conditions required to ensure efficient process of communication.

They are comprised of:

- Pedagogic space operation via creation and use of communicative situations demanding display of a complex of skills required for successful participation in cross-cultural communication;

- Sufficient motivation of trainees to foreign language learning comprised of goal orientation, activity, object-subject relations in the course of learning activity, individual-and-psychological qualities of person actuating the ability to carry out cross-cultural communication with native speakers;

- Creation of the positive emotional climate in the entire range of learning environment that promotes upbringing of a person committed to universal human values, absorbed wealth of cultural heritage of the past of native people and peoples of other countries, aimed to mutual understanding with them and ready to inter-personal and cross-cultural communication. Development of ability to crosscultural communicative competence results in positive personal changes of trainees based on reflection, orientation to achievement of other culture values, extension of civic consciousness when applying to native culture and language.

High level of computerization of society and the growing importance of the Internet as a means of storing and transmitting information require from a modern foreign language teachers introduction into educational practice of information and communication technologies. Their use contributes to the improvement of the linguistic and intercultural competences of learners, a culture of communication in the electronic environment, increasing the information culture in general and the development of computer skills: search, processing, transmission, systematization of information and presentation of the results of research activities of students [8].

There are two areas in which the Internet can bring the teaching of foreign languages to a new level. It is communication and information. The communication is carried out via email and Skype, publishing blogs, huge layers of information are contained within the world network (World Wide Web). 
The teacher's task is to create a model of real communication, which contributes to students ' natural desires and need for interaction with others, confidence in themselves and their abilities for communication. The communicative approach means training to dialogue and formation of ability to intercultural interaction that is the basis for the functioning of the Internet. Out of communication the Internet has no meaning - it is an international multinational, cross-cultural society whose livelihoods are based on the electronic communication of millions of people all over the world, speaking at the same time - the most gigantic in size and the number of participants in the conversation ever happened. Joining him on the foreign language lesson, we create a model of real communication.

Communicating in real language environment provided by the Internet, the students find themselves in these situations. Involved in a wide range of meaningful, realistic, interesting and achievable tasks, the students learn spontaneously and adequately on them to react, that stimulates creation of original utterances, not of template manipulation language formulas [8].

Communication with peers from another country may occur by electronic messaging (emailing), which gives students more time to analyze the letter and figuring out the answer, and communication can be both individual and group. The exchange of electronic messages is a great tool contributing to the development of communicative qualities of students, as well as writing skills. Socializing with peers in a foreign language, regardless of whether they are native speakers or are also learning the language, will contribute to the formation of intercultural competence of students and expand their horizons [9].

At a more advanced stage of learning, when the learners of speaking skills can be used technology allows you to communicate "live" with members of the studied culture. At the moment the most popular service that provides this capability is "Skype" (free software that provides voice communication over the Internet between computers).

Also, the Internet communication may occur through the publication of blogs. There are many educational (and not only) Internet resources where students can communicate via blogs (eng. blog, from web $\log$ — web log, online diary). An example is a service for learners of English provided by the British Broadcasting Corporation (BBC) on the pages www.bbc.co.uk. One of the most popular services for micro-blogging is Twitter www.twitter.com. After registration, members may post short messages ("twits"), on any topic. Any user can read your micro blog and immediately to answer it or to continue the theme. Although Twitter is conceived, it can be widely used for teaching writing. Posting a microblog, students can meet with their peers abroad and to continue the dialogue.

\section{Conclusion}

The success of intercultural communication depends largely on the professional competence of the teacher. A. Müller-Hartmann investigated the question of the influence of ability of teachers to adapt to new learning tools (Internet technologies) in the formation of intercultural competence. In classes where the teacher owned the Internet-technologies and methods of their integration in the process of foreign language teaching, the results of the formation of the components of intercultural competence were significantly higher than in classes where due to a technical incompetence of the teacher students gained full autonomy, but has not received instructions with the received information.

Internet resources - vast source of information that can be used by both the teachers and students. With proper organization of the educational process, in addition to communicative competence in a variety of its components students will develop information competence, which involves mastery of new information technologies, an understanding of the range of their application, as well as a critical attitude to the information disseminated [10].

Using search engines (Google, Yahoo, Yandex, etc.), you can find a huge amount of information, including concerning the culture of the country of the studied language. The task of the teacher is that in addition to the use of the proposed school textbooks and audio-visual materials, actively use the Internet resources, expanding their horizons and constantly bringing something new in their classes: it can be interesting and unusual facts about a foreign culture, authentic audio and video materials, interesting photos, illustrations, lesson plans, workbooks in General, anything that can increase students ' interest in the culture of the country of the target language will help them to take a fresh look at the culture of his country, hence raising their level of intercultural competence. Students interested in further study of a foreign language and getting acquainted with the culture of the country can successfully use Internet resources independently.

Summarizing the results of study, it may be noted that the problem of cross-cultural competence formation will not take the back seat in future. The demand for the specialists who are fluent in foreign languages and ready to interact with the representatives of other countries successfully is growing day by day. 


\begin{tabular}{l|lrl|l|ll} 
& ISRA (India) & $=\mathbf{1 . 3 4 4}$ & SIS (USA) & $=\mathbf{0 . 9 1 2}$ & ICV (Poland) & $=\mathbf{6 . 6 3 0}$ \\
Impact Factor: & ISI (Dubai, UAE) $=\mathbf{0 . 8 2 9}$ & PUHIL (Russia) $=\mathbf{0 . 1 7 9}$ & PIF (India) & $=\mathbf{1 . 9 4 0}$ \\
& GIF (Australia) & $\mathbf{0 . 5 6 4}$ & ESJI (KZ) & $=\mathbf{1 . 0 4 2}$ & IBI (India) & $\mathbf{= 4 . 2 6 0}$ \\
& JIF & $\mathbf{1 . 5 0 0}$ & SJIF (Morocco) & $=\mathbf{2 . 0 3 1}$ & & \\
\hline
\end{tabular}

\section{References:}

1. Solovova EN (2016) Methods of teaching foreign languages. Basic lectures: A Handbook for students ped. schools and teachers, 321 .

2. Sadokhin AP (2004) Intercultural Communication: Textbook, 288.

3. Elizarova GV (2005) Culture and language training, 252.

4. Baryshnikov NV (2002) Parameters of intercultural communication training in high school. Foreign languages at school, 2, 17-19.

5. Leontovich OA (2003) Modernization of the content and methods of foreign language teaching as a priority in continuous language education, 152.
6. Pluzhnik IL (2003) Formation of the intercultural communicative competence of

7. Safonova VV (2001) Cultural studies in the system of modern language education. Foreign languages at school, 3, 17-24.

8. Fischer G (1998) E-mail in foreign language teaching. Towards the creation of virtual classrooms.

9. Sysoev PV (2008) Modern educational online resources in teaching a foreign language. Foreign languages at school, 6, 2-10.

10. Kolker YM (2000) Practical methods of foreign language training: Training, 297. p. 26. 